Lubna Rashid, Khaled Alzafari, Jan Kratzer

\title{
Founder personalities, behaviors and new venture success in Sub-Saharan Africa
}

Journal article | Accepted manuscript (Postprint)

This version is available at https://doi.org/10.14279/depositonce-11459

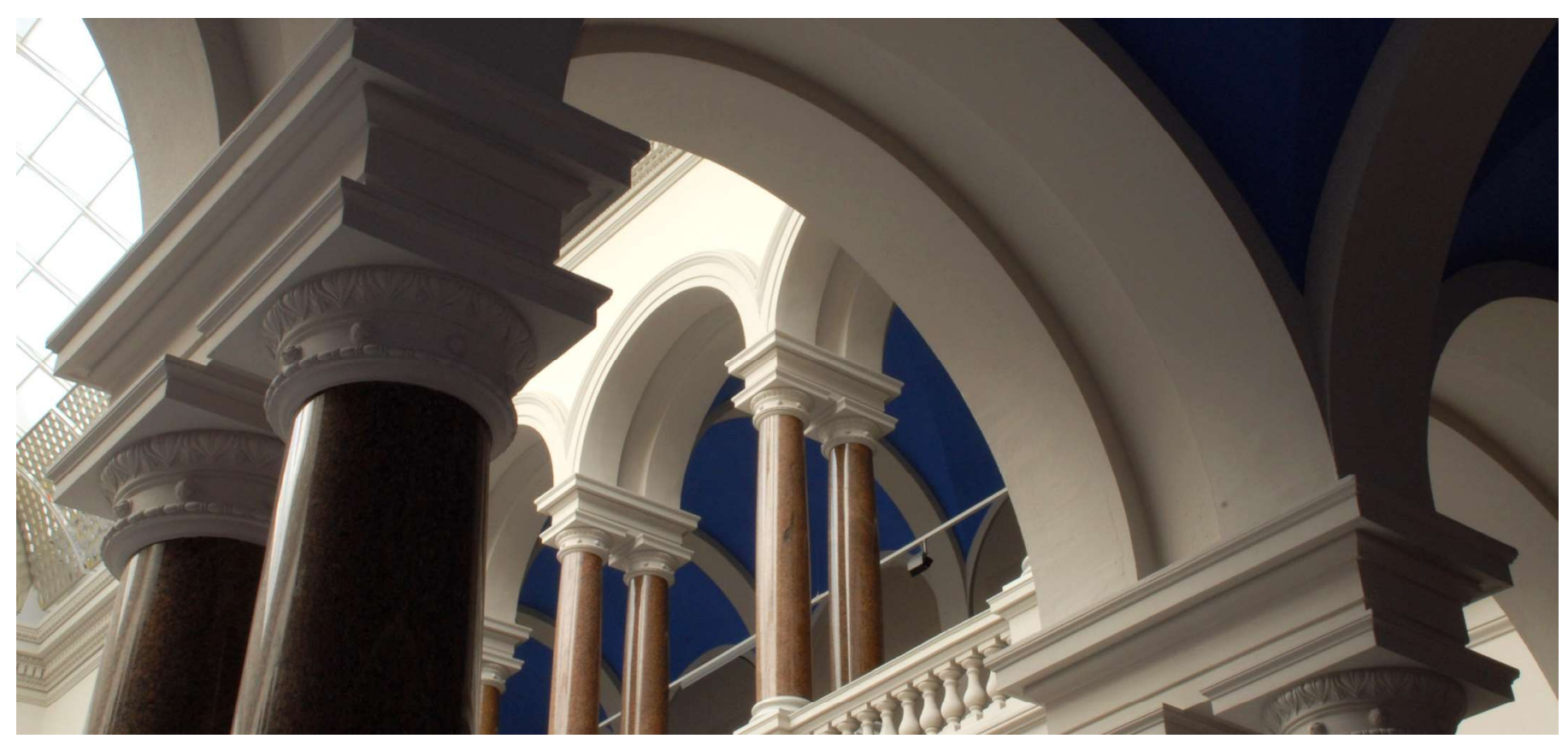

Rashid, L., Alzafari, K., \& Kratzer, J. (2020). Founder Personalities, Behaviors and New Venture Success in Sub-Saharan Africa. Technological Forecasting and Social Change, 151, 119766.

https://doi.org/10.1016/j.techfore.2019.119766 


\section{Founder Personalities, Behaviors and New Venture Success in Sub-Saharan Africa}

\section{--- Accepted Version ---}

Final version published by Technological Forecasting \& Social Change, to be cited as: Rashid, L., Alzafari, K., \& Kratzer, J. (2020). Founder Personalities, Behaviors and New Venture Success in Sub-Saharan Africa. Technological Forecasting and Social Change, 151, 119766. https://doi.org/10.1016/j.techfore.2019.119766.

Facing heightened levels of political instability and institutional fragility, several sub-Saharan African countries have been responding with innovation policies and entrepreneurship support structures. With little scholarly knowledge on who those entrepreneurs are at an individual level, however, the ability to effectively support innovative new ventures in some of the world's most compromised regions would remain limited. Based on a sample of 232 entrepreneurs, this study attempts to enlighten the relationship between personality characteristics of entrepreneurs and their behaviors and subsequent success. This study thereby extends the entrepreneurship literature applying the Five-Factor Model of Personality to a new context while enriching knowledge on the personality-behavior relationship in entrepreneurship. Several findings and theoretical concepts are synthesized while evaluating new venture success from a behavioral lens among largely innovative, social-driven entrepreneurs in sub-Saharan countries, providing important implications for research, policy, and practice.

Keywords: African Entrepreneurs, Big Five, Entrepreneurial and Managerial Behaviors, Start-up Success, Fragile States

\section{Highlights:}

- This article focuses on understanding how personality characteristics relate to entrepreneurial and managerial behaviors among sub-Saharan African entrepreneurs.

- The article employs linear regression modeling to assess the big five predictability of founder behavior and an independent sample t-test to assess behavior's predictability of entrepreneurial success.

- Conscientiousness and agreeableness appear to be the strongest personality predictors of entrepreneurial success.

- Country fragility plays a role in moderating the personality-entrepreneurial behavior relationship.

- Customized, context-appropriate entrepreneurial support approaches are needed. 


\section{Introduction}

According to estimates by the Organization for Economic Cooperation and Development (OECD), $24 \%$ of the world population currently dwells in fragile states ${ }^{1}$, the majority of whom are located in the African continent, with the number expected to increase to 3.3 billion individuals by 2050 (OECD, 2018). While this evidently calls for sustainable, bottom-up institutional development approaches beyond temporary relief (Easterly, 2008; Schramm, 2010), the lack of political stability influences business activity in Africa, with international investors directing their focus towards safer countries (Ratten \& Jones, 2018). Some African countries employ a system of micro-credits (e.g. Kato \& Kratzer, 2013), though this also requires moderate political stability and the satisfaction of basic physiological human needs.

Regardless of the challenges, "most of the countries in sub-Saharan Africa champion the development of small-and medium-sized enterprises (SMEs) as a conduit to the alleviation of poverty, the generation of employment, and the promotion of national economic development" (Robson, Haugh, \& Obeng, 2009, p. 331). However, and despite an increased research focus on entrepreneurship and innovation in Africa over the past years (e.g. Asongu, Nwachukwu, \& Orim, 2018; Dana, Ratten, \& Honyenuga, 2018; Fu, Mohnen, \& Zanello, 2018; Grimm, Knorringa, \& Lay, 2012; Naudé, 2017), scholarly knowledge of the personal characteristics of founders in Africa, and in fragile states in general, remains quite limited. Realizing the contextspecificity of personal characteristics and the impact of cultural and environmental variations on their manifestation and expression (McCrae, 2002; McCrae \& Terracciano, 2005; Tett \& Guterman, 2000), conclusions on entrepreneurial personality and behavior from western or stable contexts cannot be simply extended to African or fragile contexts.

Meanwhile over the last two decades, personality in business research has been largely investigated through the Five Factor Model (FFM) which posits five basic dimensions of human personality commonly known as the big five, namely Openness, Conscientiousness, Extraversion, Agreeableness and Emotional Stability (Barrick \& Mount, 1991; Costa \& McCrae, 1992; Gosling, Rentfrow, \& Swann, 2003; McCrae \& Costa, 2003). With relation to entrepreneurial success, however, scholars have thus far primarily focused on the founder personality's relationship to measures of firm performance (Ciavarella, Buchholtz, Riordan, Gatewood, \& Stoke, 2004; Hachana, Berraies, \& Ftiti, 2018; Matyka, Jung, \& Kratzer, 2012;

\footnotetext{
1 "Fragility is the combination of exposure to risk and insufficient coping capacity of the state, system and/or communities to manage, absorb or mitigate those risks. Fragility can lead to negative outcomes including violence, the breakdown of institutions, displacement, humanitarian crises or other emergencies" (OECD, 2016, p. 22).
} 
H. Zhao, Seibert, \& Lumpkin, 2010; L. Zhao \& Jung, 2018; M. Zhou, Zhou, Zhang, Obschonka, \& Silbereisen, 2017) rather than indicators of entrepreneurial success at the individual level. Given that long-term success of new ventures is largely the result of founder behaviors (Bird \& Schjoedt, 2017; Kodithuwakkua \& Rosa, 2002) and the variation of success definitions among different entrepreneurs (Ettl \& Welter, 2012; Reijonen, 2008; Sarasvathy, 2004), a behavioral approach to entrepreneurial assessment is certainly needed.

This research represents one of the first studies on the personality-behavior relationship in entrepreneurship and the first study addressing this topic in this particular region, employing data gathered across several sub-Saharan countries. The study builds on a synthesis of different theories, develops eight hypotheses and tests them based on a sample of 232 entrepreneurs primarily using multiple regression modelling. The results show that entrepreneurial and managerial behaviors do indeed correlate with firm performance and that conscientiousness, extraversion and agreeableness positively relate to entrepreneurial behavior moderated by country fragility. Emotional stability appears to also predict entrepreneurial behavior, though the effect vanishes when accounting for contextual moderator variables. Managerial behaviors, on the other hand, are positively predicted by conscientiousness and agreeableness, whereas openness appears to have a statistically significant U-shaped relationship to managerial behaviors.

\section{Theory and Hypotheses}

\subsection{Entrepreneurial Success from a Behavioral Lens}

Entrepreneurial success is often measured through firm performance indicators such as wealth attainment and firm growth (Fried \& Tauer, 2009; McMullen \& Shepherd, 2006; Unger, Rauch, Frese, \& Rosenbusch, 2011). However, using firm performance as proxy for entrepreneurial success could be misleading given that firm failure could enhance an entrepreneur's chance of success on the long-term (Sarasvathy, 2004). Research also shows that different entrepreneurs have heterogeneous goals and definitions of success (Ettl \& Welter, 2012; Hayter, 2011; Reijonen, 2008; Sarasvathy, 2004), which could explain why some financiallyunderperforming companies persist for a very long time (Sarasvathy, 2004). Additionally, it may be inappropriate to evaluate entrepreneurial success based on firm-level outcomes in cases where it is too early for such outcomes to have manifested, or in cases, as in some fragile countries, where bookkeeping and firm performance documentation practices are underrated or underused (e.g. Maseko \& Manyani, 2011). 
Therefore, it appears worthwhile to evaluate entrepreneurial success from a behavioral perspective, recognizing that "human behavior involved in finding and exploiting entrepreneurial opportunity through creating and developing new venture organizations" ultimately results in enhancing innovation, stimulating competition and creating new jobs and revenue streams (Bird \& Schjoedt, 2017, p. 380). Indeed, the behavior of entrepreneurs is seen as "the proximal individual-centric cause of venture outcomes (e.g., existence, sales, products, survival, and growth)" (Bird, Schjoedt, \& Baum, 2012, p. 890) and several scholars attempted to validate behavior's correlation with firm success. For example, Chandler and Jansen (1992) find that behaviors such as seizing opportunities in familiar domains, adapting to business demands, and obtaining the necessary education and expertise positively correlate with venture growth and profitability. Other behaviors such as those related to gathering and utilizing resources and long-term planning have also been found to predict long-term firm performance (Man \& Chan, 2002) and those pertaining to seeking feedback, researching potential clients and relationship development appear more prevalent in successful ventures in comparison with struggling ones (Katre \& Salipante, 2012).

The significance of an entrepreneur's behavior becomes more pronounced in challenged environments in accordance with Carsrud and Krueger (1995), who claim that entrepreneurs' behaviors (e.g. opportunity recognition and risk-taking) increase in importance with socioeconomic environmental instability. Ahmad et al. (2010) extend this argument and suggest that the exhibition of appropriate behavior by startup founders has the potential to reduce the negative impacts of environmental fragility and hostility on their business success. Kirzner (1984) argues that success in a limited-resource environment is determined by entrepreneurial capabilities, such as those pertaining to opportunity perception and resource mobilization, as well as managerial capabilities that optimize value creation from those scarce resources. Those capabilities are highly related with entrepreneurial and managerial behaviors respectively.

Hypothesis 1 (H1): Founder behaviors differ between highly-successful and less successful African entrepreneurs.

\subsection{Personality and Behavior in Entrepreneurship}

Personality comprises psychological qualities that influence and partially explain consistent and differentiating patterns of feeling, thinking and behaving (Cervone \& Pervin, 2012), therefore predisposing individuals to exhibit particular actions and, given their persistence over 
long periods of time, have astonishing capabilities to predict long-term behavior (McCrae \& Costa, 2003). Of all taxonomies and measures of personality traits, the FFM is considered the most valid, consistent and reliable (Cervone \& Pervin, 2012; Goldberg, 1993). Fathered by Tupes and Christal (1961) and heavily advanced by McCrae and Costa (1985, 1987), five key personality factors, each encompassing a larger number of specific traits, have been constructed.

Costa and McCrae's (1992) manual describes the FFM components in detail. A person high in openness is one who is creative, imaginative, untraditional, intellectually curious, has broad interests and tends to seek new experiences. A conscientious individual is reliable, diligent, organized, self-disciplined, perseverant, hard-working and has high achievement motivation. Extraversion refers to being sociable, talkative, affectionate, active, person-oriented and optimistic, while agreeableness embodies trustfulness, soft-heartedness, helpfulness, gullibility, compassion and forgivingness. Finally, an emotionally-stable person is one who is calm, satisfied, secure, relaxed, and resilient.

Studies on the big five in entrepreneurship have been mainly concerned with personality and entrepreneurial intentions (Antoncic, Bratkovic, Singh, \& DeNoble, 2015; H. Zhao et al., 2010), entrepreneurial opportunity identification (Ardichvili, Cardozo, \& Ray, 2003), venture performance (Hachana et al., 2018; H. Zhao et al., 2010; L. Zhao \& Jung, 2018) and venture life cycle (Ciavarella et al., 2004), paying little explicit attention to entrepreneurial and managerial behaviors. Notable exceptions include the works of Rauch and Frese (2000, 2007), who model specific personality traits (e.g. need for achievement and locus of control) as predictors of entrepreneur's goals, strategies and actions that ultimately result in business success, though they claim that general FFM components are too unspecific to produce reliable results as predictors of entrepreneurial behavior. However, with a myriad of studies confirming the predictive abilities of FFM components to workplace behaviors in a variety of settings (see Penney, David, \& Witt, 2011), there is no reason to believe that entrepreneurship is an exception.

The Openness dimension, for instance, positively correlates with creative behaviors as measured by tests of divergent thinking (McCrae, 1987). Openness additionally leads to higher diversity in network communication and information flows, which plays a further role in enhancing creative behaviors as studies among lead users have shown (Kratzer \& Lettl, 2009; Kratzer, Lettl, Franke, \& Gloor, 2016). Openness has also been shown to strongly correlate 
with networking behaviors including creating, maintaining and using new contacts (Wolff \& Kim, 2012) as well opportunity recognition behaviors (J. Zhou \& George, 2001). Additionally, the management of a successful new company requires constant adaptation to its dynamic environment, which requires adaptive behaviors that are expected to be influenced by openness. In a fragile country, where the need for adaptation to constant contextual challenges and creativity in problem-solving might be even higher than in stable environments, openness could play a particularly important role. Accordingly, we expect a positive link between openness and entrepreneurial and managerial behaviors.

Hypothesis 2 (H2): Openness is positively related to entrepreneurial and managerial behaviors.

The start-up process in particular requires flexibility in combination with well-coordinated project and time management, the latter being related to conscientiousness. Many scholars indeed regard conscientiousness to be the most important personality dimension for job performance and a primary work motivation variable (Barrick \& Mount, 1991; Gellatly, 1996). A meta-analysis by Hurtz and Donovan (2000) additionally revealed that with respect to task performance, job dedication and interpersonal facilitation, measured by (behavioral) indicators such as use of equipment, commitment to objectives and being a team-player respectively, conscientiousness appears to be a consistently-valid indicator. This dimension has also been found to positively correlate with proactive behaviors (Bateman \& Crant, 1993). The need for organization, discipline and diligence might be especially elevated in environments with vague institutional requirements and systemic hurdles, as would be expected in more fragile contexts. In short, this characteristic appears necessary to enhance entrepreneurial and managerial behaviors and subsequent successful entrepreneurial outcomes.

Hypothesis 3 (H3): Conscientiousness is positively related to entrepreneurial and managerial behaviors.

In turn, people with high extraversion scores are receptive to ideas and emotions (Costa \& McCrae, 1992). Markman and Baron (2003) mention the importance of building networks with suppliers and customers in an industry as a crucial part of the start-up process, which we expect to correlate with extraversion in agreement with Wolff and Kim (2012) and Zhao et al. (2010). These networking behaviors could also involve negotiation with stakeholders, interacting with own employees and team members and receiving advice from others. The ability to build strong 
networks and relationships could be more pronounced in fragile environments, where dependence on social networks and community support could be instrumental in overcoming environmental challenges and achieving entrepreneurial success (e.g. Abou-Moghli \& AlKasasbeh, 2012; Dana, Gurău, Hoy, Ramadani, \& Alexander, 2019) and is even linked to enhanced resource mobilization and opportunity recognition behaviors and capabilities (see Bhagavatula, Elfring, van Tilburg, \& van de Bunt, 2010). Extraversion has also been found to predict proactive behavior (Bateman \& Crant, 1993) as well as transformational leadership behaviors (Judge \& Bono, 2000). A meta-analytic study by Judge et al. (2002) shows extraversion to be the strongest personality predictor of management success, which could be an indicator of proper managerial behaviors. Because of these findings, we expect a positive correlation with the entrepreneur's entrepreneurial and managerial behaviors.

Hypothesis 4 (H4): Extraversion is positively related to entrepreneurial and managerial behaviors.

Agreeableness is also a dimension which describes interpersonal behavior, more specifically referring to the tendency to be pleasant in social situations. Individuals high on agreeableness are characterized as altruistic, empathetic, considerate, supportive and friendly (Graziano \& Eisenberg, 1997), all of which are characteristics that might especially be helpful where social interactions and solid networks are needed to compensate for challenges in the surrounding environment. Agreeableness has been shown to correlate positively to transformational leadership (Judge \& Bono, 2000) and the attraction of venture capital (Cable \& Shane, 1997). Agreeableness is also shown to positively predict internal networking behaviors within a company (Wolff \& Kim, 2012). We therefore expect a positive relationship between agreeableness and behaviors needed for entrepreneurial success.

Hypothesis 5 (H5): Agreeableness is positively related to entrepreneurial and managerial behaviors.

Emotional stability refers to the ability to have balanced feelings about common experiences and to act in a rational, reflected manner. Individuals who are less emotionally stable are more reactive to stress and have less endurance, making emotional stability particularly valuable in a highly stressful environment. Being capable to withstand emotional stress at the workplace is vital when starting a new business anywhere, and regions where institutional support is lacking might induce even higher levels of workplace stress. Meta-analytical findings indicate 
a positive relationship between emotional stability and job performance (Barrick, Mount, \& Judge, 2001). Additionally, running a business successfully requires a continuous learning process (Judge et al., 2002) and we expect more emotionally-stable entrepreneurs to be more effective learners. With respect to behaviors pertaining to equipment use, being a team-player and dedication to work, emotional stability has also been found as an important predictor (Hurtz \& Donovan, 2000). For this reason we expect emotional stability to be a positive indicator of entrepreneurial and managerial behaviors.

Hypothesis 6(H6): Emotional Stability is positively related to entrepreneurial and managerial behaviors.

\subsection{Context and Trait Activation}

Differences in personality characteristics (McCrae, 2002; McCrae \& Terracciano, 2005) and workplace behaviors (e.g. Middermann \& Rashid, 2019) have been noted between countries and regions, substantiating the importance of analyzing them in the African context rather than merely drawing inferences based on studies in western countries. One prominent explanation is the trait-activation theory (Judge \& Zapata, 2014; Tett \& Burnett, 2003; Tett \& Guterman, 2000), where the expression of specific personality traits is deemed contingent upon stimuli and cues in the surrounding work environment. According to this theory, a workplace behavior would only result from a personality trait if strong and relevant task-, social- and organizationrelated stimuli are present.

Clearly, the nature of job responsibilities, social expectations and organizational climates could vary significantly between countries with differing levels of institutional stability. For instance, one might expect that certain aspects of a fragile-country entrepreneurial environment, such as poorer access to basic technical services (e.g. internet connection or electricity supply), higher threats of physical violence and asset theft, lack of regulatory transparency and increased corruption as well as increased social inequality and discrimination, could trigger different expression pathways of personality characteristics compared to entrepreneurs operating in a highly-stable environment. In other words, country fragility might have an impact on the personality-behavior relationship.

Hypothesis 7 (H7): Country fragility impacts the relationships between personality dimensions and entrepreneurial and managerial behaviors. 
Differences in workplace environmental cues are also expected to differ with varying types of companies. For instance, the nature of work-related tasks and social interactions could be influenced by the age of the company as well as the nature of developed products or services (e.g. social orientation or technology-based products). Therefore, company type is also expected to impact the personality-behavior relationship.

Hypothesis 8 (H8): Company type impacts the relationships between personality dimensions and entrepreneurial and managerial behaviors.

All the aforementioned hypotheses and conceptual framework of this study are summarized in figure 1.

Figure 1: Conceptual Framework.

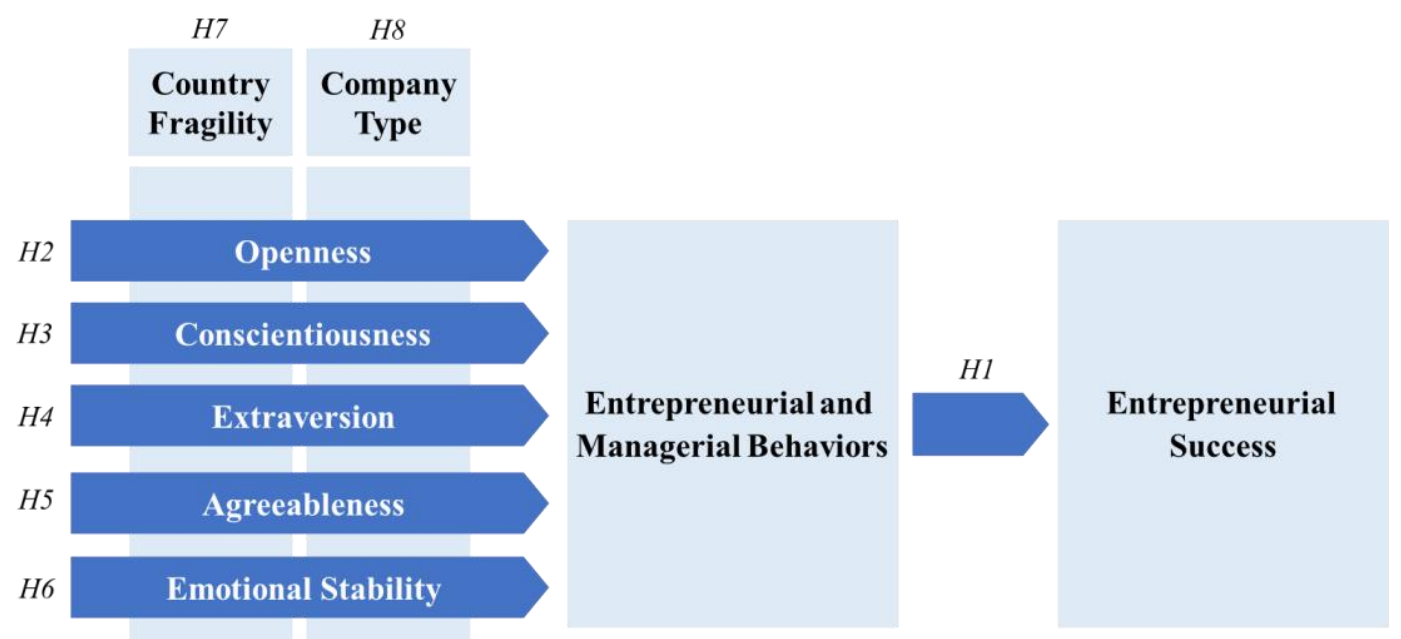

\section{Data and Methods}

\subsection{Variables}

\subsubsection{Dependent Variables}

A questionnaire was designed to test the aforementioned hypotheses. To measure entrepreneurial and managerial behaviors, we adopted the behavioral measures of performance created and validated by Brown and Hanlon (2004, 2016). These so-called Behavioural Observation Scales (BOS) are proven to account for task complexity, clarify subsequent necessary action and allow for proper coaching and support while generally exhibiting high levels of inter-rater consistency and correlation with non-behavioral performance measures 
(Brown \& Hanlon, 2016; G. P. Latham, Almost, Mann, \& Moore, 2005; G. Latham \& Wexley, 1994; Wiersma, van den Berg, \& Latham, 1995).

Brown and Hanlon's BOS has been chosen as it specifically assesses entrepreneurial and managerial behaviors which closely relate to entrepreneurial and managerial capabilities needed for new venture success in a challenged environment as identified by Israel Kirzner (1984). Brown and Hanlon (2016) classify founder behaviors into entrepreneurial ones which are primarily needed while starting up a company and managerial ones that are important for early company growth. Entrepreneurial behaviors are accordingly considered those related to the founder's acquisition of proper skills and educational background, opportunity identification, dedication to business, resource mobilization, risk-taking and negotiation, comprising a total of 23 questionnaire items. Managerial behaviors, on the other hand, are comprised of those pertaining to strategic growth, financial management, employee/team management and marketing/customer management, making up a total of 24 questionnaire items. Each questionnaire item was evaluated on a 7-point Likert scale.

Data was also collected on the annual turnover of the venture as an estimator for economic performance. Respondents were also asked to subjectively evaluate their success by answering the question "compared to other enterprises in your branch, how successful are you?" on a 7point Likert scale. Highly successful companies could therefore be identified in two different ways: Those for which the annual turnover equals or exceeds USD 10,000 and those for which the founder subjectively identifies him/herself as moderately or strongly more successful than peers.

\subsubsection{Independent Variables}

With regards to personality measurement, decades of research and methodological development have led to the creation of the widely-used 10-item Personality Inventory Measure (TIPI) as an instrument for FFM quantification (Gosling et al., 2003), which was applied in our study. So far, dozens of studies in many disciplines have successfully applied this scale (Bias, Larson, Huang, Ryan, \& Montesclaros, 2010; Ferris, Lyons, Blass, \& Hochwarter, 2009; Grant \& Ashford, 2008; Ivcevic \& Mayer, 2009; Li \& Chignell, 2010; Motowidlo \& Peterson, 2008; Poropat \& Jones, 2009). The use of the brief TIPI scale was favored against more detailed, elaborate Big Five measures (e.g. Fruyt, Bolle, McCrae, Terracciano, \& Costa, 2009; McCrae \& Costa, 2004) to avoid potentially burdening study participants with a lengthy questionnaire and enhance response rates. Each personality 
dimension was measured using 2 questions, one of which is reverse-scored. Each TIPI questionnaire item is evaluated on a 7-point Likert scale.

\subsubsection{Control and Moderating Variables}

The questionnaire also contained items measuring demographic variables such as gender and age as well as measures of the founder's surrounding environment. Company type was measured by three variables the first of which is startup stage, where we define an early-stage venture as one that is in the process of being set up over the last 12 months or less and a latestage one as being over 1 year old and already paying wages, inspired by the Global Entrepreneurship Monitor (GEM, 2019). Type of company was also identified by questions on whether the founder considers the company a social or a technology company.

Data on country of operation and location within the country was also collected and countries were classified as fragile or non-fragile based on the latest OECD country fragility classification (OECD, 2018). The OECD classifies a country as fragile based on dimensions of economic, environmental, political, security and societal risk (OECD, 2016), considering the state's current exposure to negative events across those dimensions in addition to the its capacity to deal with related and resulting risks in the future.

\subsection{Data Collection}

The questionnaire was distributed online to start-up founders across sub-Saharan Africa through established connections with managers of incubator, accelerator and networking programs focused on new venture support in the region. The major collaborator was the Tony Elumelu Foundation, a non-profit organization that trains and invests in potentially highgrowth African start-ups across the continent. Additional data was collected through organizations including (but not limited to) the Heartland Incubation Hub in Nigeria and Pangea Accelerator in Kenya. The data was collected between September 2018 and January 2019 through SurveyMonkey software. All questionnaire items were marked as mandatory to ensure completeness of collected data. The final dataset consists of 232 individual responses (response rate $=18.4 \%$ ) from an estimated population of 1261 entrepreneurs.

\subsection{Validity and Reliability Tests}

The questionnaire reliability was examined through Cronbach's $\alpha$ measurement to assert that the items measuring entrepreneurial and managerial behaviors do so adequately. A Cronbach's $\alpha$ value of 0.85 was obtained for each dependent variable. The Kaiser-Meyer-Olkin (KMO) 
test results also indicate sampling adequacy for each dependent variable. Those results are summarized in table 1.

There is no anticipation of non-response bias given that all questionnaire items required mandatory responses. As for common method variance (CMV), we follow Fuller et al. (2016, p. 3192) in presuming that a "relatively high level of CMV must be present to bias true relationships among substantive variables at typically reported reliability levels" and that "at levels of CMV typical of multiple item measures with typical reliabilities reporting typical effect sizes, CMV does not represent a grave threat to the validity of research findings". We also refrained from conducting a confirmatory factor analysis (Harman's one-factor test) to detect CMV in accordance with Fuller et al. (2016) and Podsakoff et al. (2003), who postulate that this test is not sensitive enough to detect CMV and that there is a lack of empirical evidence that proves its efficacy.

Table 1: Summary of analysis results pertaining to questionnaire validation.

\begin{tabular}{|l|l|l|l|}
\hline $\begin{array}{l}\text { Dependent } \\
\text { Variables }\end{array}$ & Constituent Elements & \multirow{2}{*}{ Cronbach's $\alpha$} & KMO \\
\hline \multirow{4}{*}{$\begin{array}{l}\text { Entrepreneurial } \\
\text { Behaviors }\end{array}$} & Relevant Background for Chosen Business & & \\
\cline { 2 - 2 } & Opportunity Identification & \multirow{3}{*}{0.85} & \multirow{3}{*}{0.86} \\
\cline { 2 - 2 } & Dedication to Business & & \\
\cline { 2 - 2 } $\begin{array}{l}\text { Managerial } \\
\text { Behaviors }\end{array}$ & Negotiation and Risk-Taking & & \\
\cline { 2 - 2 } & Strategic Business Development and Growth & & \\
\cline { 2 - 2 } & Financial Management Skills & & \\
\cline { 2 - 2 } & Employee Management & & \\
\cline { 2 - 3 } & Marketing/ Customer Relations Management & & \\
\hline
\end{tabular}

\subsection{Hypothesis Testing}

Data analysis was performed using the Statistical Package for the Social Sciences (SPSS). After computing descriptive statistics on variable means, standard deviations, frequencies and Pearson correlation coefficients, an independent sample t-test was administered to compare mean scores on entrepreneurial and managerial behaviors between highly successful and less successful ventures to test hypothesis 1 . Linear regression modeling was then performed to test the remaining hypotheses. The independent variables were also quadratically transformed and centered to test for possible non-linear effects. Regression models were established separately for each dependent variable while controlling for gender and age. Contextual variables (i.e. 
those pertaining to company type and country fragility) were tested for possible moderation effects (hypotheses 7 and 8).

\section{Findings}

\subsection{Descriptive Statistics}

The 232 respondents come from a total of 22 countries across sub-Saharan Africa primarily from Nigeria (49.1\%), Kenya (15.9\%), Uganda (10.3\%), Ghana (4.7\%) and Tanzania (3.9\%). The vast majority of respondents live in the same country in which they were born (92.3\%) and in urban areas (73.0\%). Female-identifying entrepreneurs constitute a quarter of the sample (24.1\%) and the majority of respondents $(72.8 \%)$ are between 25 and 39 years of age. Over $80 \%$ of study participants have at least a bachelor's degree.

Analyzed founders operate across a variety of industries with almost all companies being forprofit (97.4\%). Most of the founders operate social (74.1\%), technology-based (78.0\%) startups that are less than 12-months old (62.9\%). When asked to subjectively evaluate their business success, $77.6 \%$ of respondents indicated being at least a little more successful than other enterprises in their branch while $47.0 \%$ consider themselves moderately or strongly more successful. With respect to financial metrics, $53.9 \%$ of founders indicated no or less than 5\% sales growth compared to last year and $40.5 \%$ have obtained at least 1 round of investment from venture investors. The majority of businesses operate only locally $(86.2 \%)$.

Respondents appear to have similar scores on entrepreneurial and managerial behaviors, with mean scores of 5.92 and 5.98 (out of 7) respectively. As for independent variables, respondents scored highest on conscientiousness (mean=6.31) and lowest on extraversion (mean=4.48). Additional detail on variable means, standard deviations (SD) and correlation coefficients are found in tables 2-4. 
Table 2: Descriptive Statistics regarding the dependent variables.

\begin{tabular}{|c|c|c|c|c|c|}
\hline Dependent Variables & Mean & $S D$ & Constituent Elements & Mean & $S D$ \\
\hline \multirow{5}{*}{$\begin{array}{l}\text { Entrepreneurial } \\
\text { Behaviors }\end{array}$} & \multirow{5}{*}{5.92} & \multirow{5}{*}{.77} & Relevant Background for Chosen Business & 5.77 & 1.09 \\
\hline & & & Opportunity Identification & 6.14 & .96 \\
\hline & & & Dedication to Business & 6.36 & .67 \\
\hline & & & Mobilizing Support and Resources from Others & 5.86 & .83 \\
\hline & & & Negotiation and Risk-Taking & 5.47 & 1.20 \\
\hline \multirow{4}{*}{ Managerial Behaviors } & \multirow{4}{*}{5.98} & \multirow{4}{*}{.78} & Strategic Business Development and Growth & 6.16 & .76 \\
\hline & & & Financial Management Skills & 5.65 & .98 \\
\hline & & & Employee Management & 6.17 & 1.07 \\
\hline & & & Marketing/ Customer Relations Management & 5.95 & .91 \\
\hline
\end{tabular}

Table 3: Descriptive Statistics regarding the independent variables.

\begin{tabular}{|l|l|l|}
\hline Independent Variables & Mean & SD \\
\hline Extraversion & 4.48 & 1.41 \\
\hline Agreeableness & 5.55 & 1.13 \\
\hline Conscientiousness & 6.31 & .94 \\
\hline Emotional Stability & 5.79 & 1.20 \\
\hline Openness & 6.42 & .82 \\
\hline
\end{tabular}


Table 4: Pearson correlations between the dependent and independent variables.

\begin{tabular}{|c|c|c|c|c|c|c|c|c|}
\hline & & $\begin{array}{l}\text { Entrepreneurial } \\
\text { Behaviors }\end{array}$ & $\begin{array}{l}\text { Managerial } \\
\text { Behaviors }\end{array}$ & Extraversion & Agreeableness & Conscientiousness & $\begin{array}{l}\text { Emotional } \\
\text { Stability }\end{array}$ & Openness \\
\hline \multirow{3}{*}{ Entrepreneurial Behaviors } & Pearson Correlation & 1 & $.891 * *$ & $.220 * *$ & $.190 * *$ & $.404^{* *}$ & $.313 * *$ & $.316^{* *}$ \\
\hline & Sig. (2-tailed) & & .000 & .001 & .004 & .000 & .000 & .000 \\
\hline & $\mathrm{N}$ & 232 & 232 & 224 & 224 & 224 & 224 & 224 \\
\hline \multirow{3}{*}{ Managerial Behaviors } & Pearson Correlation & $.891 * *$ & 1 & $.174 * *$ & $.172 * *$ & $.388^{* *}$ & $.317 * *$ & $.246^{* *}$ \\
\hline & Sig. (2-tailed) & .000 & & .009 & .010 & .000 & .000 & .000 \\
\hline & $\mathrm{N}$ & 232 & 232 & 224 & 224 & 224 & 224 & 224 \\
\hline \multirow{3}{*}{ Extraversion } & Pearson Correlation & $.220 * *$ & $.174 * *$ & 1 & -.129 & .103 & .088 & $.256 * *$ \\
\hline & Sig. (2-tailed) & .001 & .009 & & .053 & .126 & .189 & .000 \\
\hline & $\mathrm{N}$ & 224 & 224 & 224 & 224 & 224 & 224 & 224 \\
\hline \multirow{3}{*}{ Agreeableness } & Pearson Correlation & $.190 * *$ & $.172 * *$ & -.129 & 1 & $.195 * *$ & $.298 * *$ & .119 \\
\hline & Sig. (2-tailed) & .004 & .010 & .053 & & .003 & .000 & .076 \\
\hline & $\mathrm{N}$ & 224 & 224 & 224 & 224 & 224 & 224 & 224 \\
\hline \multirow{3}{*}{ Conscientiousness } & Pearson Correlation & $.404 * *$ & $.388^{* *}$ & .103 & $.195 * *$ & 1 & $.430 * *$ & $.402 * *$ \\
\hline & Sig. (2-tailed) & .000 & .000 & .126 & .003 & & .000 & .000 \\
\hline & $\mathrm{N}$ & 224 & 224 & 224 & 224 & 224 & 224 & 224 \\
\hline \multirow{3}{*}{ Emotional Stability } & Pearson Correlation & $.313 * *$ & $.317 * *$ & .088 & $.298 * *$ & $.430 * *$ & 1 & $.313 * *$ \\
\hline & Sig. (2-tailed) & .000 & .000 & .189 & .000 & .000 & & .000 \\
\hline & $\mathrm{N}$ & 224 & 224 & 224 & 224 & 224 & 224 & 224 \\
\hline \multirow{3}{*}{ Openness } & Pearson Correlation & $.316^{* *}$ & $.246 * *$ & $.256 * *$ & .119 & $.402 * *$ & $.313 * *$ & 1 \\
\hline & Sig. (2-tailed) & .000 & .000 & .000 & .076 & .000 & .000 & \\
\hline & $\mathrm{N}$ & 224 & 224 & 224 & 224 & 224 & 224 & 224 \\
\hline
\end{tabular}




\subsection{Hypothesis Testing}

An independent sample t-test was administered to compare the mean scores on entrepreneurial and managerial behaviors by grouping the overall sample based on the two aforementioned measures of entrepreneurial success. Results indicate a significant mean difference (supporting hypothesis 1 ), as seen in table 5 .

Table 5: Results from independent sample t-tests evaluating mean score differences between groups of founders based on subjectively- and economically evaluated firm success.

\begin{tabular}{|l|l|l|l|l|l|l|}
\hline \multirow{2}{*}{ Grouping Variable } & \multirow{2}{*}{$\begin{array}{l}\text { Test } \\
\text { Variables }\end{array}$} & \multicolumn{3}{|l|}{ T-Test for Equality of Means } \\
\cline { 3 - 7 } & & $\mathrm{t}$ & $\mathrm{df}$ & $\begin{array}{l}\text { Sig. (2- } \\
\text { tailed) }\end{array}$ & $\begin{array}{l}\text { Mean } \\
\text { Difference }\end{array}$ & $\begin{array}{l}\text { Std. Error } \\
\text { Difference }\end{array}$ \\
\hline $\begin{array}{l}\text { Self-Rated as Highly } \\
\text { Successful }\end{array}$ & Entrepreneurial Behaviors & -4.32 & 230.00 & 0.00 & -0.42 & 0.10 \\
\cline { 2 - 7 } & Managerial Behaviors & -4.75 & 230.00 & 0.00 & -0.47 & 0.10 \\
\hline $\begin{array}{l}\text { Annual Turnover } \\
\geq \$ 10 \mathrm{~K}\end{array}$ & Entrepreneurial Behaviors & -3.10 & 229.96 & 0.00 & -0.30 & 0.10 \\
\cline { 2 - 7 } & Managerial Behaviors & -4.43 & 222.48 & 0.00 & -0.41 & 0.09 \\
\hline
\end{tabular}

Linear regression modeling results are summarized in tables 6-7. All models have significant regression equations with no multicollinearity detected (all VIF values < 10).

The results show partial confirmation of hypotheses 2-8. Conscientiousness appears to be the independent variable with the strongest significant $(p<0.01)$ positive correlation with both entrepreneurial and managerial behaviors. Agreeableness also appears to significantly ( $p$ $<0.05)$ predict entrepreneurial and managerial behaviors, albeit to a smaller degree.

As for the remaining personality variables, emotional stability does not appear to have a significant correlation with managerial behaviors and its significant correlation with entrepreneurial behaviors diminishes when accounting for moderator variables. Extraversion appears to significantly $(\mathrm{p}<0.01)$ predict entrepreneurial but not managerial behaviors with a small effect $(B=0.09)$, while openness appears to significantly predict managerial $(p<0.05)$ rather than entrepreneurial behaviors with evidence of a U-shaped relationship.

With regards to the control and moderating variables, gender appears to have a significant influence on entrepreneurial and managerial behaviors, with male gender positively and strongly predicting both. Country fragility also has a strong, significant positive correlation with entrepreneurial behaviors, albeit not with managerial behaviors, and appears to moderate the effect of emotional stability. Variables pertaining to founder age, start-up stage and company type (social or tech) appear insignificant in all models tested. 
Table 6: Linear Regression Models Predicting Entrepreneurial Behaviors.

\begin{tabular}{|c|c|c|c|c|c|c|c|c|}
\hline \multirow[b]{2}{*}{ Variable } & \multicolumn{2}{|c|}{ Model 1} & \multicolumn{2}{|c|}{ Model 2} & \multicolumn{2}{|c|}{ Model 3} & \multicolumn{2}{|c|}{ Model 4} \\
\hline & $B$ & $S E B$ & $B$ & $S E B$ & $B$ & $S E B$ & $B$ & $S E B$ \\
\hline \multicolumn{9}{|l|}{ Control Variables } \\
\hline Gender (DV: Male) & $0,38^{* *}$ & 0,12 & $0,35^{* *}$ & 0,10 & $0,35^{* *}$ & 0,10 & $0,31 * *$ & 0,11 \\
\hline Age (DV: Less than 30) & $-0,12$ & 0,16 & 0,05 & 0,14 & 0,04 & 0,14 & 0,01 & 0,15 \\
\hline Age (DV: Between 30-39) & $-0,22$ & 0,16 & $-0,06$ & 0,14 & $-0,06$ & 0,14 & $-0,12$ & 0,14 \\
\hline \multicolumn{9}{|l|}{ Independent Variables (Linear) } \\
\hline Extraversion & & & $0,08 *$ & 0,03 & $0,08 *$ & 0,03 & $0,09 * *$ & 0,03 \\
\hline Agreeableness & & & $0,09 *$ & 0,04 & $0,12 *$ & 0,05 & $0,12 *$ & 0,05 \\
\hline Conscientiousness & & & $0,24 * *$ & 0,06 & $0,30 * *$ & 0,10 & $0,29 * *$ & 0,10 \\
\hline Emotional Stability & & & 0,08 & 0,04 & $0,12 *$ & 0,06 & 0,11 & 0,06 \\
\hline Openness & & & 0,10 & 0,06 & 0,14 & 0,10 & 0,12 & 0,10 \\
\hline \multicolumn{9}{|l|}{ Independent Variables (Quadratic) } \\
\hline Quadratic Extraversion & & & & & 0,00 & 0,02 & 0,00 & 0,02 \\
\hline Quadratic Agreeableness & & & & & 0,05 & 0,03 & 0,04 & 0,03 \\
\hline Quadratic conscientiousness & & & & & 0,07 & 0,06 & 0,08 & 0,06 \\
\hline Quadratic Emotional Stability & & & & & 0,02 & 0,03 & 0,02 & 0,03 \\
\hline Quadratic Openness & & & & & 0,04 & 0,05 & 0,03 & 0,05 \\
\hline \multicolumn{9}{|l|}{ Moderating Variables } \\
\hline Start-up Phase (DV: Early Stage) & & & & & & & $-0,08$ & 0,10 \\
\hline Company Type (DV: Tech Start-up) & & & & & & & 0,11 & 0,12 \\
\hline Company Type (DV: Social Start-up) & & & & & & & 0,08 & 0,11 \\
\hline Country Fragility (DV: Fragile State) & & & & & & & $\mathbf{0 , 3 1} *$ & 0,15 \\
\hline$R^{2}$ & 0,055 & & 0,296 & & 0,324 & & 0,344 & \\
\hline
\end{tabular}

DV: Dummy Variable

$* \mathrm{p}<=.05, * * \mathrm{p}<=.01$ 
Table 7: Linear Regression Models Predicting Managerial Behaviors.

\begin{tabular}{|c|c|c|c|c|c|c|c|c|}
\hline \multirow[b]{2}{*}{ Variable } & \multicolumn{2}{|c|}{ Model 1} & \multicolumn{2}{|c|}{ Model 2} & \multicolumn{2}{|c|}{ Model 3} & \multicolumn{2}{|c|}{ Model 4} \\
\hline & $B$ & $S E B$ & $B$ & $S E B$ & $B$ & $S E B$ & $B$ & $S E B$ \\
\hline \multicolumn{9}{|l|}{ Control Variables } \\
\hline Gender (DV: Male) & $0,30 *$ & 0,12 & $0,27 *$ & 0,11 & $0,27 *$ & 0,11 & $0,25 * *$ & 0,11 \\
\hline Age (DV: Less than 30) & $-0,18$ & 0,16 & 0,01 & 0,15 & 0,01 & 0,15 & 0,05 & 0,15 \\
\hline Age (DV: Between 30-39) & $-0,21$ & 0,16 & $-0,04$ & 0,15 & $-0,03$ & 0,15 & $-0,03$ & 0,15 \\
\hline \multicolumn{9}{|l|}{ Independent Variables (Linear) } \\
\hline Extraversion & & & 0,06 & 0,04 & $0,07 *$ & 0,04 & 0,07 & 0,04 \\
\hline Agreeableness & & & 0,08 & 0,05 & $0,10 *$ & 0,05 & $\mathbf{0 , 1 1} *$ & 0,05 \\
\hline Conscientiousness & & & $0,25 * *$ & 0,06 & $0,31 * *$ & 0,10 & $\mathbf{0 , 3 1} * *$ & 0,10 \\
\hline Emotional Stability & & & $0,10 *$ & 0,05 & 0,10 & 0,06 & 0,09 & 0,06 \\
\hline Openness & & & 0,04 & 0,07 & $0,21 *$ & 0,10 & 0,20 & 0,10 \\
\hline \multicolumn{9}{|l|}{ Independent Variables (Quadratic) } \\
\hline Quadratic Extraversion & & & & & 0,00 & 0,02 & 0,00 & 0,02 \\
\hline Quadratic Agreeableness & & & & & 0,05 & 0,03 & 0,05 & 0,03 \\
\hline Quadratic conscientiousness & & & & & 0,07 & 0,06 & 0,07 & 0,06 \\
\hline Quadratic Emotional Stability & & & & & $-0,02$ & 0,03 & $-0,02$ & 0,03 \\
\hline Quadratic Openness & & & & & $0,13 *$ & 0,05 & $0,12 *$ & 0,05 \\
\hline \multicolumn{9}{|l|}{ Moderating Variables } \\
\hline Start-up Phase (DV: Early Stage) & & & & & & & $-0,18$ & 0,10 \\
\hline Company Type (DV: Tech Start-up) & & & & & & & $-0,01$ & 0,12 \\
\hline Company Type (DV: Social Start-up) & & & & & & & 0,07 & 0,11 \\
\hline Country Fragility (DV: Fragile State) & & & & & & & 0,20 & 0,16 \\
\hline$R^{2}$ & 0,035 & & 0,246 & & 0,289 & & 0,306 & \\
\hline
\end{tabular}

DV: Dummy Variable

$* \mathrm{p}<=.05, * * \mathrm{p}<=.01$ 


\section{Discussion and Implications}

First of all, the findings confirm that entrepreneurial and managerial behaviors significantly correlate with entrepreneurial success. This supports overcoming the limitations and challenges of concrete economic measures such as turnover, size, market share and profit, which though potentially more objectively measured, fail when comparing entrepreneurial endeavors across different industries, company stages and country contexts.

The results with respect to entrepreneurial behaviors show statistically significant and positive effects of the independent variables extraversion, conscientiousness and agreeableness. The variable emotional stability is moderated by country fragility as suggested earlier in the paper. Therefore, it appears that the more fragile a country is, the more emotional stability is needed to be successful as an entrepreneur.

Those overall results demonstrate that individuals exhibiting high levels of entrepreneurial behavior are generally reliable, well-organized, trustful and helpful and to a lower extent talkative and optimistic together with some ego-centered orientation. Thus, entrepreneurs actively exercising entrepreneurial behaviors are champions to only some extent while carrying additional characteristics (Gemuenden, 1985; Howell, Shea, \& Higgins, 2005; Kratzer, Gemuenden, \& Hoelzle, 2010; Rost, Hölzle, \& Gemuenden, 2007).

The findings concerning managerial behaviors also demonstrate the positive and statistically significant predictive capabilities of agreeableness and conscientiousness. Translated into reality, this indicates that the reliable, diligent, well-organized, trustful and helpful entrepreneurs, rather than the ego-centered champions, are most successful. Indeed, although entrepreneurs are often described as champions and extroverts, the reality appears to be different, at least in the sub-Saharan context.

Perhaps unexpectedly, the variable openness has a U-shaped statistically significant relationship with managerial behaviors. A possible explanation is that some successful African enterprises might have a strictly local focus hence very low degrees of openness, while others reach out to larger regions or even internationally where openness is a pre-condition for successful. This could also signal the mixed innovative versus replicative nature of studied entrepreneurs (Baumol, 2010). This finding warrants further investigation into the role of openness in African and fragile-country entrepreneurial success. 
Theoretically, the paper reaffirms the importance of personality traits for start-up performance. However, this paper extents the empirical body of research with unique data from Africa. The results strongly indicate that exhibiting needed behaviors and achieving success as an entrepreneur requires a blend of various personality characteristics which cannot be generalized from one country context to another. The paper extends the application of the trait activation theory to the sub Saharan African context and confirms the influence of country fragility on personality expression and subsequent entrepreneurial behavior, a unique contribution to entrepreneurship literature combining theoretical rigor with social relevance (see Wiklund, Wright, \& Zahra, 2019).

Primarily agreeableness and conscientiousness appear to determine the behavior of entrepreneurs. Recognizing behavior's connection to entrepreneurial success, results support earlier findings that consider agreeableness the most important predictive personality dimension with respect to attracting financial means and conscientiousness as the most important one for intrinsic motivation and job performance (Barrick et al., 2001; Cable \& Shane, 1997). The results cannot confirm earlier findings on the value of extraversion (e.g. Shane, 2003) while negating previous findings on the negative correlation of agreeableness with new venture success, presumably due to agreeableness's negative relationship with autonomy and acting independently of social expectations which had generally been associated with successful entrepreneurship (Brandstätter, 2011).

These results could be attributed to the general collectivistic nature of most sub-Saharan African cultures, where collectivism is associated with lower levels of extraversion (Hofstede \& McCrae, 2004). Additionally, the expression of empathy and compassion, which highly relates to agreeableness (Chopik, O'Brien, \& Konrath, 2017), is generally found to positively correlate with low income and poverty (Kraus, Côté, \& Keltner, 2012; Stellar, Manzo, Kraus, \& Keltner, 2012) - common issues in highly-fragile countries. Additionally, helpfulness, trustworthiness and altruism might prove vital to successfully act in social networks and work as a community to develop endogenously amidst fragile conditions. Moreover, being wellorganized while embedded in administrative and business conditions that are deficient in organization might be particularly vital in fragile countries.

From a practical point of view, understanding the relationship between personality dimensions, entrepreneurs' behavior and subsequent new business success in Africa is positioned to nurture entrepreneurs and start-up teams without relying on potentially irrelevant knowledge gathered 
in western, institutionally stable countries. The results might assist in selecting the more-fitting entrepreneurs for acceleration/incubation support and/or customizing support and coaching programs to best fit regional needs.

Entrepreneurship activities in sub-Saharan Africa might therefore require the fostering of alternative sets of soft skills, thus different training and education approaches, compared with stable, western countries (see Rashid, 2019). Entrepreneurial team composition might also need be differently done to maximize success. This emphasizes that supporters, non-profit organizations and public and private institutions ought not simply transfer educational efforts and support strategies but have to adapt all initiatives to local conditions (Ojala \& Heikkilä, 2011).

Results also help in selecting receivers of financial means from public sources and venture capitalists. Particularly, many believe that the most successful entrepreneurs are ego-centered individualists while the results indicate something else. This also includes foreign investment efforts, where investors needs to realize that the loudest entrepreneurs are not necessarily the most promising. In other words, a typical Silicon-Valley mentality probably fails to achieve entrepreneurial success and secure local financial investments in the African context.

The results might even warrant the need for different coaching and financing strategies for African and fragile-country migrant or refugee entrepreneurs attempting to start businesses in western and stable countries (Rashid, 2018), recognizing differences in their personal characteristics. Additionally, realizing that male gender is significantly correlated to entrepreneurial and managerial behaviors calls for more specialized efforts to understand and foster female entrepreneurship in the region.

\section{Conclusions}

With the sub-Saharan region being home to most of the world's low income, highly fragile countries (Fund for Peace, 2019; World Bank, 2018), it is necessary to focus on empowering bottom-up developmental approaches emphasizing high-growth business development. This study attempts to reveal some of the individual-level determinants of the recent economic revival in the region resulting from entrepreneurial activity (Naudé, 2017). Personality has long been considered of major importance in predicting business outcomes and entrepreneurial intention and success, but its relationship to the entrepreneur's behavior has been largely understudied. In addition, although manifestations of personality traits in entrepreneurship are 
expected to differ significantly with country context, studies thus far have primarily focused on western and stable environments.

This study offers new insights on those matters based on quantitative analysis of a dataset of 232 African entrepreneurs. The FFM has been employed to assess personality dimensions, while entrepreneurial success has been viewed from a behavioral lens with a focus on individual entrepreneurial and managerial behaviors. Results indicate that indeed, entrepreneurial and managerial behaviors correlate with new venture success and that conscientiousness and agreeableness, moderated by country fragility, are the strongest personality predictors of those behaviors.

The study responds to recent calls to diversify entrepreneurship research (Welter, Baker, Audretsch, \& Gartner, 2017) and conduct research that is both high in theoretical rigor and social relevance (Wiklund et al., 2019). This research particularly addresses entrepreneurship literature gaps regarding the personality-behavior relationship and personality research outside of stable, western countries. Findings additionally support education, team building and financing efforts for African entrepreneurs and call for specialized and context-appropriate development initiatives.

As with all studies, some limitations are identified. One limitation is in the data itself; gathering data around start-up support organizations (Tony Elumelu Foundation, Heartland Incubation Hub and Pangea Accelerator among others) certainly biases the resulting sample. Only entrepreneurs who are part of these entities were reached, therefore limiting the sample to formal entrepreneurship endeavors as well as those with regular internet access due to the use of a digital questionnaire. The magnitude and impact of informal entrepreneurs particularly in African countries is however not to be underestimated. Although it could be quite challenging to collect reliable data about informal entrepreneurship activities in fragile countries, it is important to do so particularly given the positive role that the informal sector plays in entrepreneurial development (e.g. Naudé, 2010).

Additionally, collecting data using self-reported questionnaires occasionally results in some degree of response subjectivity. For instance, social desirability bias is not uncommon, where "respondents may systematically alter questionnaire responses in the direction they perceive to be desired by the investigator" (Choi \& Pak, 2005, p. 8). This might explain the relatively high mean scores obtained on both entrepreneurial and managerial behaviors. However, measures have been taken to reduce such biases such as allowing all respondents to submit their 
questionnaires with full anonymity in addition to asking them to rate themselves from the perspective of a trusted advisor rather than their personal perspective; the latter being a technique specifically proven to reduce social desirability bias (Brown \& Hanlon, 2016; Schoorman \& Mayer, 2007).

Finally, Africa is a large continent within which exist many societal, economic, political and cultural differences. Though we attempted to partially offset this intra-variability by including country fragility measures, future research should concentrate on individual countries and explore the nature of personal traits and resulting entrepreneurial and managerial behaviors indepth within specific contexts. Future research should moreover include additional variables concerning the institutional conditions and support systems on the country level. This could also be done across several countries using hierarchical modelling or in comparison to highly stable countries.

Additional possible moderating and also mediating variables could be explored in future research in order to further refine the results and practical recommendations. Personality characteristics of founders could be supplemented by and compared with other independent variables such as social networks, cultural capital or family background. All in all, research that links personal traits, entrepreneurial activities and success should pay more attention to changing global dynamics and major sustainability and social challenges, determinants of entrepreneurship beyond pure profit orientations, modifications in and extensions of institutional support mechanisms and changing labor markets due to effects of digitalization.

\section{Acknowledgements}

We would like to express our gratitude to the individuals and organizations that supported our research operations. Special thanks to Mr. Uwem Uwemapkan (Tony Elumelu Foundation), Mr. Kolapo Ogungbile (Oluaka Academy and the Heartland Incubation Hub) and Ms. Anne Lawi (Pangea Accelerator) for supporting the majority of our data collection efforts. We would also like to acknowledge Ms. Omepeju Afanu (WomenX 12), Ms. Jovanna Alvarez (Ongoza), Mr. Oluwakemi Olaoye (MindtheGap), Mr. John Kieti (Nairobi Innovation Week), Ms. Toyin Dania (MBC Africa), Mr. Joshua Adedeji (ASPEN Institute) and Mr. Kevin Thiong'o (SPRING Accelerator).

Copyright: (C) 2019. This manuscript version is made available under the CC-BY-NC-ND 4.0 license http://creativecommons.org/licenses/by-nc-nd/4.0/. 


\section{References}

Abou-Moghli, A. A., \& Al-Kasasbeh, M. M. (2012). Social Network and the Success of Business Start-Up. International Journal of Business and Management, 7(9), 134-140.

Ahmad, N. H., Ramayah, T., Wilson, C., \& Kummerow, L. (2010). Is Entrepreneurial Competency and Business Success Relationship Contingent upon Business Environment? A Study of Malaysian SMEs. International Journal of Entrepreneurial Behaviour \& Research, 16(3), 182-203. https://doi.org/10.1108/13552551011042780

Antoncic, B., Bratkovic, T. K., Singh, G., \& DeNoble, A. F. (2015). The Big Five PersonalityEntrepreneurship Relationship: Evidence from Slovenia. Journal of Small Business Management, 53(3), 819-841.

Ardichvili, A. A., Cardozo, R. N., \& Ray, S. (2003). A Theory of Entrepreneurial Opportunity Identification and Development. Journal of Business Venturing, 18(1), 105-123.

Asongu, S. A., Nwachukwu, J. C., \& Orim, S.-M. I. (2018). Mobile phones, institutional quality and entrepreneurship in Sub-Saharan Africa. Technological Forecasting and Social Change, 181, 183-203. https://doi.org/10.1016/j.techfore.2017.08.007

Barrick, M. R., \& Mount, M. K. (1991). The Big Five personality dimensions and job performance: A meta-analysis. Personnel Psychology, 44, 1-26.

Barrick, M. R., Mount, M. K., \& Judge, T. A. (2001). Personality and Performance at the Beginning of the New Millennium: What Do We Know and Where Do We Go Next? International Journal of Selection and Assessment, 9(1-2), 9-30.

Bateman, T. S., \& Crant, J. M. (1993). The Proactive Component of Organizational Behavior: A Measure and Correlates. Journal of Organizational Behavior, 14(2), 103-118.

Baumol, W. J. (2010). The Microtheory of Innovative Entrepreneurship. Princeton and Oxford: Princeton University Press.

Bhagavatula, S., Elfring, T., van Tilburg, A., \& van de Bunt, G. G. (2010). How Social and Human Capital Influence Opportunity Recognition and Resource Mobilization in India's Handloom Industry. Journal of Business Venturing, 25(3), 245-260. https://doi.org/doi.org/10.1016/j.jbusvent.2008.10.006

Bias, R. G., Larson, K., Huang, S.-C., Ryan, P. R., \& Montesclaros, C. (2010). An Exploratory Study of Visual and Psychological Correlates of Preference for Onscreen SubpixelRendered Text. Journal of the American Society for Information Science and Technology, 61(4), 745-757. 
Bird, B., \& Schjoedt, L. (2017). Entrepreneurial Behavior: Its Nature, Scope, Recent Research, and Agenda for Future Research. Cham: Springer.

Bird, B., Schjoedt, L., \& Baum, J. R. (2012). Editor's Introduction. Entrepreneurs' Behavior: Elucidation and Measurement. Entrepreneurship Theory and Practice, 36(5), 889-913.

Brandstätter, H. (2011). Personality Aspects of Entrepreneurship: A Look at Five MetaAnalyses. Personality and Individual Differences, 51, 222-230. https://doi.org/10.1016/j.paid.2010.07.007

Brown, T. C., \& Hanlon, D. (2004). Developing Behavioural Observation Scales to Foster Effective Entrepreneurship. Journal of Small Business \& Entrepreneurship, 17(2), 103-116.

Brown, T. C., \& Hanlon, D. (2016). Behavioral Criteria for Grounding Entrepreneurship Education and Training Programs: A Validation Study. Journal of Small Business Management, 54(2), 399-419.

Cable, D. M., \& Shane, S. (1997). A Prisoner's Dilemma Approach to Entrepreneur-Venture Capitalist Relationships. Academy of Management Review, 22, 142-176.

Carsrud, A., \& Krueger, N. F. (1995). Entrepreneurship and Social Psychology: Behavioral Technology for the New Venture Initiation Process. In J. A. Katz \& R. H. Brockhaus (Eds.), Advances in Entrepreneurship, Firm Emergence, and Growth (Vol. 2, pp. 7396). Greenwich, CT: JAI Press.

Cervone, D., \& Pervin, L. A. (2012). Personality: Theory and Research (12th ed.). Hoboken: Wiley.

Chandler, G. N., \& Jansen, E. (1992). The Founder's Self-Assessed Competence and Venture Performance. Journal of Business Venturing, 7(3), 223-236.

Choi, B. C. K., \& Pak, A. W. P. (2005). A Catalog of Biases in Questionnaires. Preventing Chronic Disease, 2(1).

Chopik, W. J., O’Brien, E., \& Konrath, S. H. (2017). Differences in Empathic Concern and Perspective Taking Across 63 Countries. Journal of Cross-Cultural Psychology, 48(1), 23-38. https://doi.org/10.1177/0022022116673910

Ciavarella, M. A., Buchholtz, A. K., Riordan, C. M., Gatewood, R. D., \& Stoke, G. S. (2004). The Big Five and Venture Survival: Is There a Linkage? Journal of Business Venturing, 19, 465-483. https://doi.org/10.1016/j.jbusvent.2003.03.001

Costa, P. T., \& McCrae, R. R. (1992). Revised NEO Personality Inventory (NEO-PI-R) and NEO Five Factor Inventory (NEO-FFI) Professional Manual. Odessa: PAR. 
Dana, L.-P., Gurău, C., Hoy, F., Ramadani, V., \& Alexander, T. (2019). Success Factors and Challenges of Grassroots Innovations: Learning from Failure. Technological Forecasting and Social Change, 119600. https://doi.org/doi.org/10.1016/j.techfore.2019.03.009

Dana, L.-P., Ratten, V., \& Honyenuga, B. Q. (2018). African Entrepreneurship: Challenges and Opportunities for Doing Business. Cham, Switzerland: Palgrave Macmillan.

Easterly, W. (2008). Institutions: Top Down or Bottom Up? American Economic Review: Papers \& Proceedings, 98(2), 95-99.

Ettl, K., \& Welter, F. (2012). Women Entrepreneurs and Success. In Women's Entrepreneurship and Economics (pp. 73-88). New York, NY: Springer.

Ferris, G. R., Lyons, L., Blass, F. R., \& Hochwarter, W. A. (2009). Interaction of Job-Limiting Pain and Political Skill on Job Satisfaction and Organizational Citizenship Behavior. Journal of Managerial Psychology, 24(7/8), 584-608.

Fried, H. O., \& Tauer, L. W. (2009). Understanding the Entrepreneur: An Index of Entrepreneurial Success. Frontiers of Entrepreneurship Research, 29(5), Article 7.

Fruyt, F. D., Bolle, M. D., McCrae, R. R., Terracciano, A., \& Costa, P. T. (2009). Assessing the Universal Structure of Personality in Early Adolescence: The NEO-PI-R and NEOPI-3 in 24 Cultures. Assessment, 16(3), 301-311.

Fu, X., Mohnen, P., \& Zanello, G. (2018). Innovation and productivity in formal and informal firms in Ghana. Technological Forecasting and Social Change, 131, 315-325. https://doi.org/10.1016/j.techfore.2017.08.009

Fuller, C. M., Simmering, M. J., Atinc, G., Atinc, Y., \& Babin, B. J. (2016). Common Methods Variance Detection in Business Research. Journal of Business Research, 69, 31923198. https://doi.org/10.1016/j.jbusres.2015.12.008

Fund for Peace. (2019). Global Data | Fragile States Index. Retrieved from https://fragilestatesindex.org/data/

Gellatly, I. R. (1996). Conscientiousness and Job Performance: Test of a Cognitive Process Model. Journal of Applied Psychology, 81, 474-482.

GEM. (2019). How GEM Defines Entrepreneurship. Retrieved from https://www.gemconsortium.org/wiki/1149

Gemuenden, H. G. (1985). Promotors-Key Persons for the Development and Marketing of Innovative Industrial Products. Berlin/Heidelberg/New York/Tokyo: Springer.

Goldberg, L. R. (1993). The Structure of Phenotypic Personality Traits. American Psychologist, 48(1), 26-34. 
Gosling, S. D., Rentfrow, P. J., \& Swann, W. B. Jr. (2003). A Very Brief Measure of the BigFive Personality Domains. Journal of Research in Personality, 37, 504-528.

Grant, A. M., \& Ashford, S. J. (2008). The Dynamics of Proactivity at Work. Research in Organizational Behavior, 28, 3-34.

Graziano, W. G., \& Eisenberg, N. (1997). Agreeableness; A Dimension of Personality. San Diego: Academic Press.

Grimm, M., Knorringa, P., \& Lay, J. (2012). Constrained Gazelles: High Potentials in West Africa's Informal Economy. World Development, 40(7), 1352-1368. https://doi.org/10.1016/j.worlddev.2012.03.009

Hachana, R., Berraies, S., \& Ftiti, Z. (2018). Identifying Personality Traits Associated with Entrepreneurial Success: Does Gender Matter? Journal of Innovation Economics \& Management, 3(27), 169-193. https://doi.org/10.3917/jie.027.0169

Hayter, C. S. (2011). In Search of the Profit-Maximizing Actor: Motivations and Definitions of Success from Nascent Academic Entrepreneurs. The Journal of Technology Transfer, 36(3), 340-352. https://doi.org/10.1007/s10961-010-9196-1

Hofstede, G., \& McCrae, R. R. (2004). Personality and Culture Revisited: Linking Traits and Dimensions of Culture. Cross-Cultural Research, 38(1), 52-88.

Howell, J. M., Shea, C. M., \& Higgins, C. A. (2005). Champions of Product Innovations: Defining, Developing and Validating a Measure of Champion Behavior. Journal of Business Venturing, 20, 641-661.

Hurtz, G. M., \& Donovan, J. J. (2000). Personality and Job Performance: The Big Five Revisited. Journal of Applied Psychology, 85(6), 869-879.

Ivcevic, Z., \& Mayer, J. D. (2009). Mapping Dimensions of Creativity in the Life-Space. Creativity Research Journal, 21(2/3), 152-165.

Judge, T. A., \& Bono, J. E. (2000). Five-Factor Model of Personality and Transformational Leadership. Journal of Applied Psychology, 85(5), 751-765.

Judge, T. A., Bono, J. E., Ilies, R., \& Gerhardt, M. W. (2002). Personality and Leadership: A Qualitative and Quantitative Review. Journal of Applied Psychology, 87(4), 765-780.

Judge, T. A., \& Zapata, C. P. (2014). The Person-Situation Debate Revisited: Effect of Situation Strength and Trait Activation on the Validity of the Big Five Personality Traits in Predicting Job Performance. Academy of Management Journal, 58(4), 11491179.

Kato, M. P., \& Kratzer, J. (2013). Empowering Women through Microfinance: Evidence from Tanzania. ACRN Journal of Entrepreneurship Perspectives, 2(1), 31-59. 
Katre, A., \& Salipante, P. (2012). Start-Up Social Ventures: Blending Fine-Grained Behaviors from Two Institutions for Entrepreneurial Success. Entrepreneurship Theory and Practice, 36(5), 967-994. https://doi.org/10.1111/j.1540-6520.2012.00536.x

Kirzner, I. M. (1984). The Entrepreneurial Process. New York: Lexington Books.

Kodithuwakkua, S. S., \& Rosa, P. (2002). The Entrepreneurial Process and Economic Success in a Constrained Environment. Journal of Business Venturing, 17(5), 431-465. https://doi.org/10.1016/S0883-9026(01)00074-X

Kratzer, J., Gemuenden, H. G., \& Hoelzle, K. (2010). How the Network Position of R\&D Team Managers and Members Impact their Evaluations of Creative Performance. Creativity and Innovation Management, 19, 107-118.

Kratzer, J., \& Lettl, C. (2009). The Distinctive Role of Lead Users and Opinion Leaders in the Social Networks of School Children. Journal of Consumer Research, 36, 646-659.

Kratzer, J., Lettl, C., Franke, N., \& Gloor, P. A. (2016). The Social Network Position of Lead Users. Journal of Product Innovation Management, 33, 201-216.

Kraus, M. W., Côté, S., \& Keltner, D. (2012). Social Class, Contextualism, and Empathic Accuracy. Psychological $\quad$ Science, $21(11), \quad 1716-1723$. https://doi.org/10.1177/0956797610387613

Latham, G. P., Almost, J., Mann, S., \& Moore, C. (2005). New Developments in Performance Management. Organizational Dynamics, 34(1), 77-87.

Latham, G., \& Wexley, K. (1994). Increasing Productivity through Performance Appraisal (2nd ed.). Reading: Addison-Wesley.

Li, J., \& Chignell, M. (2010). Birds of a Feather: How Personality Influences Blog Writing and Reading. International Journal of Human-Computer Studies, 68(9), 589-602.

Man, T. W. Y., \& Chan, T. L. K. F. (2002). The Competitiveness of Small and Medium Enterprises: A Conceptualization with Focus on Entrepreneurial Competencies. Journal of Business Venturing, 17(2), 123-142.

Markman, G. D., \& Baron, R. A. (2003). Person-Entrepreneurship Fit: Why Some People are More Successful as Entrepreneurs Than Others. Human Resource Management Review, $13,281-301$.

Maseko, N., \& Manyani, O. (2011). Accounting Practices of SMEs in Zimbabwe: An Investigative Study of Record Keeping for Performance Measurement (A Case Study of Bindura). Journal of Accounting and Taxation, 3(8), 171-181. https://doi.org/10.5897/JAT11.031 
Matyka, D., Jung, St., \& Kratzer, J. (2012). Company Success Among German Internet Startups. Hamburg: Disserta Verlag.

McCrae, R. R. (1987). Creativity, Divergent Thinking, and Openness Represented in Natural Language? European Journal of Personality, 4, 119-129.

McCrae, R. R. (2002). NEO-PI-R Data from 36 Cultures: Further Intercultural Comparisons. New York: Kluwer Academic/Plenum.

McCrae, R. R., \& Costa, P. (1985). Updating Norman's “adequate taxonomy": Intelligence and personality dimensions in natural language and in questionnaires. Journal of Personality and Social Psychology, 49, 710-721.

McCrae, R. R., \& Costa, P. (1987). Validation of the Five-Factor Model of Personality Across Instruments and Observers. Journal of Personality and Social Psychology, 52, 81-90.

McCrae, R. R., \& Costa, P. T. (2004). A Contemplated Revision of the NEO Five-Factor Inventory. Personality and Individual Differences, 36(3), 587-596.

McCrae, R. R., \& Costa, P. T. J. (2003). Personality in Adulthood: A Five-Factor Theory Perspective (2nd ed.). New York: The Guilford Press.

McCrae, R. R., \& Terracciano, A. (2005). Universal Features of Personality Traits From the Observer's Perspective: Data from 50 Cultures. Journal of Personality and Social Psychology, 88(3), 547-561.

McMullen, J. S., \& Shepherd, D. A. (2006). Entrepreneurial Action and the Role of Uncertainty in the Theory of the Entrepreneur. Academy of Management Review, 31(1), 132-152.

Middermann, L. H., \& Rashid, L. (2019). Cross-Country Differences in Entrepreneurial Internationalization Tendencies: Evidence from Germany and Pakistan. Administrative Sciences, 9(3), 54. https://doi.org/10.3390/admsci9030054

Motowidlo, S. J., \& Peterson, N. G. (2008). Effects of Organizational Perspective on Implicit Trait Policies About Correctional Officers' Job Performance. Human Performance, 21(4), 396-413.

Naudé, W. (2010). Entrepreneurship, Developing Countries, and Development Economics: New Approaches and Insights. Small Business Economics, 34, 1-12.

Naudé, W. (2017). Entrepreneurship, Education and the Fourth Industrial Revolution in Africa. Bonn: IZA - Institute of Labor Economics, IZA Discussion Papers, No. 10855.

OECD. (2016). States of Fragility 2016: Understanding Violence. https://doi.org/10.1787/9789264267213-en

OECD. (2018). States of Fragility 2018: Highlights. Paris: Organisation for Economic Cooperation and Development. 
Penney, L. M., David, E., \& Witt, L. A. (2011). A Review of Personality and Performance: Identifying Boundaries, Contingencies, and Future Research Directions. Human Resource Management Review, 297-310.

Podsakoff, P. M., Mackenzie, S. B., Lee, J.-Y., \& Podsakoff, N. P. (2003). Common Method Biases in Behavioral Research: A Critical Review of the Literature and Recommended Remedies. Journal of Applied Psychology, 88(5), 879-903. https://doi.org/10.1037/0021-9010.88.5.879

Poropat, A. E., \& Jones, L. (2009). Development and Validation of a Unifactorial Measure of Citizenship Performance. Journal of Occupational and Organizational Psychology, $82(4), 851-869$.

Rashid, L. (2018). "Call Me a Business Owner, Not a Refugee!” Challenges of and Perspectives on Newcomer Entrepreneurship. Waterloo: Center for International Governance Innovation, World Refugee Council, Working Paper No.7.

Rashid, L. (2019). Entrepreneurship Education and Sustainable Development Goals: A literature Review and a Closer Look at Fragile States and Technology-Enabled Approaches. Sustainability, 11(19), 5343. https://doi.org/10.3390/su11195343

Ratten, V., \& Jones, P. (2018). Bringing Africa into Entrepreneurship Research. Basingstoke: Springer; Palgrave Macmillan.

Rauch, A., \& Frese, M. (2000). Psychological Approaches to Entrepreneurial Success: A General Model and an Overview of Findings. Chichester: Wiley.

Rauch, A., \& Frese, M. (2007). Let's Put the Person Back into Entrepreneurship Research: A Meta-Analysis on the Relationship Between Business Owners' Personality Traits, Business Creation, and Success. European Journal of Work and Organizational, 16(4), $353-385$.

Reijonen, H. (2008). Understanding the Small Business Owner: What They Really Aim at and How This Relates to Firm Performance: A Case Study in North Karelia, Eastern Finland. Management Research News, 31(8), 616-629. https://doi.org/10.1108/01409170810892172

Robson, P. J. A., Haugh, H. M., \& Obeng, B. A. (2009). Entrepreneurship and Innovation in Ghana: Enterprising Africa. Small Business Economics, 32, 331-350.

Rost, K., Hölzle, K., \& Gemuenden, H. G. (2007). Promotors or Champians? Pros and Cons of Role Specialisation for Economic Progress. Schmalenbachs Business Review, 59, 340363. 
Sarasvathy, S. (2004). Making It Happen: Beyond Theories of the Firm to Theories of Firm Design. Entrepreneurship Theory and Practice, 28(6).

Schoorman, F. D., \& Mayer, R. C. (2007). The Value of Common Perspectives in SelfReported Appraisals: You Get What You Ask For. Organizational Research Methods, 11(1), 148-159. https://doi.org/10.1177/1094428107307168

Schramm, C. J. (2010). Expeditionary Economics: Spurring Growth After Conflicts and Disasters. Foreign Affairs, 89(3), 89-99.

Shane, S. (2003). A General Theory of Entrepreneurship: The Individual-Opportunity Nexus. Cheltenham, UK and Northhampton, MA: Edward Elgar.

Stellar, J. E., Manzo, V. M., Kraus, M. W., \& Keltner, D. (2012). Class and Compassion: Socioeconomic Factors Predict Responses to Suffering. Emotion, 12(3), 449-459. https://doi.org/10.1037/a0026508

Tett, R. P., \& Burnett, D. D. (2003). A Personality Trait-Based Interactionist Model of Job Performance. Journal of Applied Psychology, 88(3), 500-517.

Tett, R. P., \& Guterman, H. A. (2000). Situation Trait Relevance, Trait Expression, and CrossSituational Consistency: Testing a Principle of Trait Activation. Journal of Research in Personality, 34, 397-423.

Tupes, E. C., \& Christal, R. E. (1961). Recurrent Personality Factors Based on Trait Ratings, USAF ASD Tech. Rep. No. 61-97. Lackland Air Force Base: TX: US Air Force.

Unger, J. M., Rauch, A., Frese, M., \& Rosenbusch, N. (2011). Human Capital and Entrepreneurial Success: A Meta-Analytical Review. Journal of Business Venturing, 26(3), 341-358.

Welter, F., Baker, T., Audretsch, D. B., \& Gartner, W. B. (2017). Everyday EntrepreneurshipA Call for Entrepreneurship Research to Embrace Entrepreneurial Diversity. Entrepreneurship Theory and Practice, 41(3), 311-321.

Wiersma, U. J., van den Berg, P. T., \& Latham, G. P. (1995). Dutch Reactions to Behavioral Observation, Behavioral Expectation, and Trait Scales. Group and Organization Management, 20, 297-309.

Wiklund, J., Wright, M., \& Zahra, S. A. (2019). Conquering Relevance: Entrepreneurship Research's Grand Challenge. Entrepreneurship Theory and Practice, 43(3), 419-436.

Wolff, H., \& Kim, S. (2012). The Relationship Between Networking Behaviors and the Big Five Personality Dimensions. Career Development International, 17(1), 43-66.

World Bank. (2018). Information Note: The World Bank Group's Harmonized List of Fragile $\begin{array}{lllll}\text { Situations. } & \text { Retrieved } & \text { March } & \text { 9, 2019, from }\end{array}$ 
http://pubdocs.worldbank.org/en/586581437416356109/FCS-List-FY16-InformationNote.pdf

Zhao, H., Seibert, S. E., \& Lumpkin, G. T. (2010). The Relationship of Personality to Entrepreneurial Intentions and Performance: A Meta-Analytic Review. Journal of Management, 36(2), 381-404. https://doi.org/1177/0149206309335187

Zhao, L., \& Jung, H.-B. (2018). The Winning Personality: Impact of Founders' Personality Traits and Firms' Network Relationships on Chinese Apparel New Venture Performance. International Journal of Entrepreneurial Behavior \& Research, 24(2), 553-573. https://doi.org/10.1108/ IJEBR-09-2016-0281

Zhou, J., \& George, J. M. (2001). When Openness to Experience and Conscientiousness are Related to Creative Behavior: An Interactional Approach. Journal of Applied Psychology, 86(3), 513-524. https://doi.org/10.1037/0021-9010.86.3.513

Zhou, M., Zhou, Y., Zhang, J., Obschonka, M., \& Silbereisen, R. K. (2017). Person-City Personality Fit and Entrepreneurial Success: An Explorative Study in China. International Journal of Psychology, 54(2), 155-163. https://doi.org/doi.org/10.1002/ijop.12451 